\title{
Endoscopic ultrasound-guided transrectal pelvic abscess drainage using a lumen- apposing metal stent
}

A 31-year-old woman with asthma presented with 1 week of lower abdominal pain and fevers after a recent emergency room discharge for appendicitis that had been managed conservatively with antibiotics. Upon presentation, she underwent a computed tomography (CT) scan of the abdomen and pelvis, which revealed a multiloculated pelvic abscess measuring approximately $7.3 \times$ $4.7 \times 7.0 \mathrm{~cm}$ ( $\boldsymbol{F i g . 1}$ ). The collection was thought to be unamenable to drainage by interventional radiology.

The patient underwent a lower gastrointestinal endoscopic ultrasound (EUS), which identified the pelvic abscess from the rectosigmoid colon. After color flow Doppler had been used to ensure there was no intervening vasculature, a cautery-enhanced delivery system was used to deploy a 10-mm lumen-apposing metal stent (LAMS; Axios; Boston Scientific, Marlborough, Massachusetts, USA) into the collection, with the distal flange in the collection and the proximal end in the sigmoid colon. This process was visualized under fluoroscopic, endosonographic, and endoscopic guidance. Copious amounts of purulent material

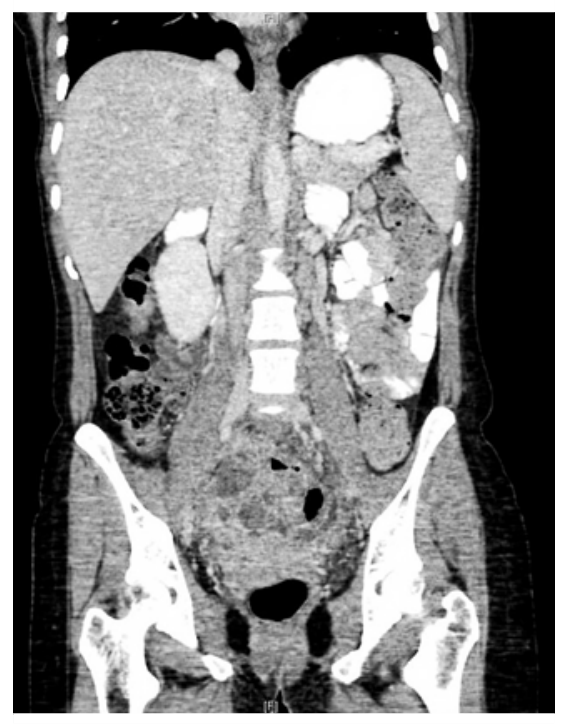

- Fig. 1 Computed tomography scan of the abdomen and pelvis showing a multiloculated pelvic abscess measuring approximately $7.3 \times 4.7 \times 7.0 \mathrm{~cm}$.

were seen draining from the stent. The stent was then dilated and two doublepigtail plastic stents $(10 \mathrm{Fr} \times 7 \mathrm{~cm})$ were deployed into the metal stent to prevent migration ( $\vee$ Video 1$)$.

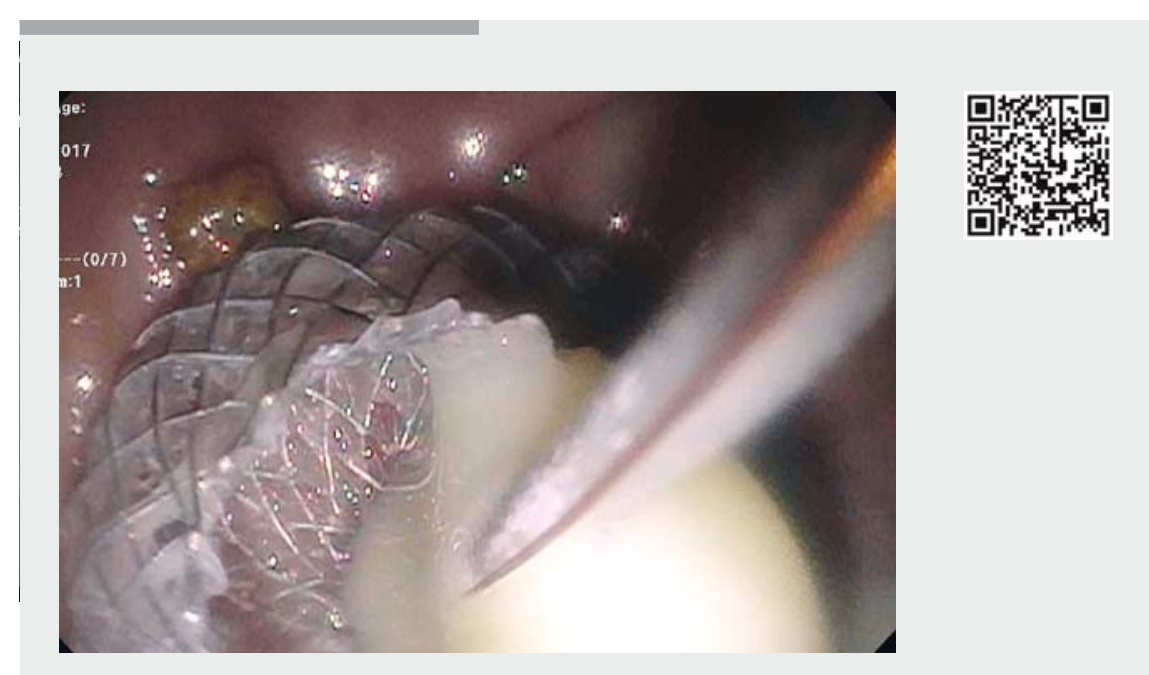

Video 1 Endoscopic ultrasound-guided transrectal abscess drainage using a lumenapposing metal stent (LAMS).
The patient was discharged on hospital day 4 after an uncomplicated post-operative course. A repeat CT scan of the abdomen and pelvis was performed nearly 3 weeks later and revealed resolution of the multiloculated pelvic abscess; the LAMS was endoscopically removed a few days later. The patient was subsequently seen in follow-up and has continued to remain asymptomatic.

The use of LAMSs has revolutionized EUS as it creates a large conduit for drainage, as well as for passage of both the endoscope and a variety of endoscopic accessories [1]. While surgical resection has been the main approach to drainage of intra-abdominal and pelvic collections, EUS can be a useful modality to aid in the diagnosis and for therapeutic drainage of pelvic collections [2-5].

Endoscopy_UCTN_Code_TTT_1AS_2AZ

Competing interests

Reem Z. Sharaiha is a consultant for Boston Scientific and Apollo Endosurgery.

The authors

Shawn L. Shah', Salem Karadesh', Enad Dawod', Monica Saumoy', Cheguevara Afaneh $^{2}$, Reem Z. Sharaiha ${ }^{1}$

1 Division of Gastroenterology and Hepatology, New York-Presbyterian/Weill Cornell Medical Center, New York, New York, USA

2 Department of Surgery, New YorkPresbyterian/Weill Cornell Medical Center, New York, New York, USA

Corresponding author

Reem Z. Sharaiha, MD, MSc

1305 York Ave, 4th, Floor, New York, NY, 10065, USA

rsharaiha@gmail.com 


\section{References}

[1] Hammad T, Khan MA, Alastal Y et al. Efficacy and safety of lumen-apposing metal stents in management of pancreatic fluid collections: are they better than plastic stents? A systematic review and meta-analysis. Dig Dis Sci 2018; 63: 289-301

[2] Donatelli G, Dumont JL, Cereatti F et al. EUSguided transrectal evacuation of organized pelvic collection following Roux-en-Y gastric bypass after failure of radiological and surgical approach. Obes Surg 2018; 28: 595 596

[3] Kawakami H, Kuwatani M, Kawahata S et al. Endoscopic ultrasound-guided pelvic abscess drainage using a dedicated, wide, flared-end, fully covered self-expandable metal stent. Endoscopy 2015; 47 (Suppl. 01): E265 - E266
[4] Luigiano C, Togliani T, Cennamo V et al. Transrectal endoscopic ultrasound-guided drainage of pelvic abscess with placement of a fully covered self-expandable metal stent. Endoscopy 2013; 45 (Suppl. 02): E245 E246

[5] Poincloux L, Caillol F, Allimant C et al. Longterm outcome of endoscopic ultrasoundguided pelvic abscess drainage: a two-center series. Endoscopy 2017; 49: 484-490

\section{Bibliography}

DOI https://doi.org/10.1055/a-0624-1609

Published online: 28.6.2018

Endoscopy 2018; 50: E254-E255

(c) Georg Thieme Verlag KG

Stuttgart · New York

ISSN 0013-726X
ENDOSCOPY E-VIDEOS

https://eref.thieme.de/e-videos

口回 Endoscopy E-Videos is a free access online section, reporting 田: on interesting cases and new techniques in gastroenterological endoscopy. All papers include a high quality video and all contributions are freely accessible online.

This section has its own submission website at https://mc.manuscriptcentral.com/e-videos 